\title{
Malign Arrhytmia Development Due to Propafenone Over Dose: a Case Report
}

\author{
Propafenon Aşırı Dozuna Bağlı Gelişen \\ Malign Aritmi: Olgu Sunumu
}

\author{
Ethem ACAR, Latif DURAN, ${ }^{2}$ Yahya ŞAHIN, ${ }^{2}$ Hızır Ufuk AKDEMiR, ${ }^{2}$ Mehmet EKiz,, ${ }^{2}$ Ali Kemal ERENLER ${ }^{3}$ \\ 'Department of Emergency Medicine, Erzurum Region Training and Research Hospital, Erzurum; \\ ${ }^{2}$ Department of Emergency Medicine, Ondokuz Mayıs University Faculty of Medicine, Samsun; \\ ${ }^{3}$ Department of Emergency Medicine, Corum State Hospital, Corum, all in Turkey
}

\begin{abstract}
SUMMARY
Propafenone is a group $1 \mathrm{C}$ antiarrhytmic agent. It is an agent used in patients with symptomatic supraventricular tachycardia requiring treatment, such as atrioventricular node tachycardia, Wolff-Parkinson-White Syndrome and paroxysmal atrial fibrillation. It is also used in life-threatining symptomatic ventricular tachycardia requiring treatment and with excessive intake it has serious side effects on cardiovascular, gastrointestinal, nervous, haematological and dermatological systems. In this report, we present a case of propafenone intake with suicidal purpose and we aim to share our experience with malign arrhytmia development and arrhytmia management. A 22-year-old female patient presented to our emergency department with complaints of general situation distortion and feeling sick after ingesting 20 pills $(6 \mathrm{~g})$ of her friend's Propafenone $\mathrm{HCl} 300 \mathrm{mg}$ for suicidal purpose one hour previously. In the electrocardiography (ECG), regular rhythm, wide QRS and the absence of P-wave was observed. Pulseless ventricular tachycardia developed and defibrillation with 360 joule was performed followed by cardiopulmonary resuscitation. $\mathrm{NaHCO}_{3}$ administration of $1 \mathrm{mEq} / \mathrm{kg}$ every 4 hours was initiated. After the therapy, QRS duration shortened. The patient became conscious with spontaneous ventilation. Early diagnosis and appropriate resuscitative interventions can be vital in propafenone intoxication. $\mathrm{NaHCO}_{3}$ administration in the presence of hypotension and ECG abnormalities are vital.
\end{abstract}

Key words: Intoxication; malign arrhytmia; prorafenon.

\section{ÖZET}

Propafenon grup 1C antiaritmik ajandır. Atriyoventrikül düğümü taşikardileri, Wolff-Parkinson-White sendromu veya paroksismal atriyal fibrilasyonu olan hastalardaki supraventriküler taşikardiler gibi tedavi gerektiren semptomatik supraventriküler taşiaritmiler ve tedavi gereği görülen, yaşamı tehdit eden semptomatik ventriküler taşiaritmilerde kullanılan; yüksek doz alımında kardiovasküler sistem, gastrointestinal sistem, sinir sistemi, hematolojik sistem ve deri üzerinde ciddi yan etkisi olan bir ilaçtır. Bu yazıda, intihar amaçlı propafenon alan bir olguyu sunarak, malign aritmi gelişimi ve yönetimi hakkındaki deneyimimizi paylaşmak istedik. Yirmi iki yaşında kadın hasta yaklaşık 1 saat önce arkadaşının propafenon HCL 300 mg'lık ilacından intihar amaçlı 20 tb (6 g) aldıktan sonra genel durum bozukluğu şikayeti ile acil servisimize başvurdu. Çekilen elektrokardiografisinde (ECG) ritmin düzenli, QRS'in geniş ve P dalgasının olmadığı görüldü. Sonrasında nabızsız ventriküler taşikardi (VT) gelişti ve kardiopulmoner resüsitasyon ve 360 joul ile defibrilasyon yapıldı. $1 \mathrm{mEq} / \mathrm{kg}$ dan $\mathrm{NaHCO}_{3}$ her 4 saatte bir verildi, bu tedaviden sonra QRS süresinin kısaldığı hastanın spontan solumaya başladığı görüldü. Propafenon zehirlenmesinde erken tanı ve uygun resüsitasyon girişimlerinin yapılması hayat kurtarıcı olabilmektedir. Hipotansiyon ve EKG bulguları varlığında $\mathrm{NaHCO}_{3}$ tedavisi verilmesi gerekmektedir.

Anahtar sözcükler: Intoksikasyon; maling aritmi; propofenon. 


\section{Introduction}

Propafenone is a group 1C antiarrhytmic agent. ${ }^{[1]}$ It is an agent used in patients with symptomatic supraventricular tachycardia requiring treatment such as atrioventricular (AV) node tachycardia and paroxysmal atrial fibrillation. It is also used in life-threatining symptomatic ventricular tachycardia requiring treatment. With excessive intake propafenone has serious side effects on cardiovascular, gastrointestinal, nervous, haematological and dermatological systems. ${ }^{[2,3]}$ In propafenone intoxication, wide complex tachycardias, right bundle branch blocks, first degree AV block, prolonged QT interval, and generalized seizures can be observed. ${ }^{[3,4]}$ Even though propafenone is a widely used class $1 \mathrm{C}$ antiarrhytmic, cases of fatal acute propafenone intake are rarely reported in the literature. ${ }^{[1]}$

In this report, we present a case of excess propafenone hydrocloride $(\mathrm{HCl})$ intake with suicidal purpose and we aim to share our experience with malign arrhytmia development and arrhytmia management.

\section{Case Report}

A 22-year-old female patient presented to our emergency department with complaints of general situation distortion and generalized discomfort after ingesting 20 pills $(6 \mathrm{~g})$ of her friend's Propafenone $\mathrm{HCl} 300 \mathrm{mg}$ for suicidal purpose one hour previously. On admission to emergency service, she had a general situation distortion with a consciousness level of stupor. She also had a superficial ventilation of 12/ $\mathrm{min}$, pulse of $64 / \mathrm{min}$ and blood pressure of $80 / 60 \mathrm{mmHg}$. Other physical examination findings were normal. The patient was transferred to the resuscitation room, supplemental oxygen therapy was initiated, an intrvenous (IV) route was obtained and endotracheal intubation was performed because of patient's inability to maintain an open airway. Blood glucose level checked from the finger tip was normal. The patient was given $1000 \mathrm{cc}$ physiological saline in $15 \mathrm{~min}$ utes. In the electrocardiography (ECG), regular rhythm, wide QRS and the absence of $p$ - wave was observed. We identified this as accelerating idioventricular rhythm. QRS duration was $148 \mathrm{~ms}$ and heart rate (HR) was 80 beats per minute (Fig. 1). Then $1 \mathrm{mEq} / \mathrm{kg} \mathrm{NaHCO}$, was administered by IV. A cardiology consultation was performed. The patient developed a generalized tonic-clonic epileptic seizure in the following one or two minutes which was ceased with $5 \mathrm{mg}$ IV diazepam. Pulseless ventricular tachycardia developed and defibrillation with 360 joule was performed followed by cardiopulmonary resuscitation (CPR) (Fig. 2). After a 30 minute period of CPR in which pulseless VT develpoed five times and defibrillation with 360 joules was applied, pulsed rhytm was obtained. Heart rate was $90 / \mathrm{min}$ and blood pressure

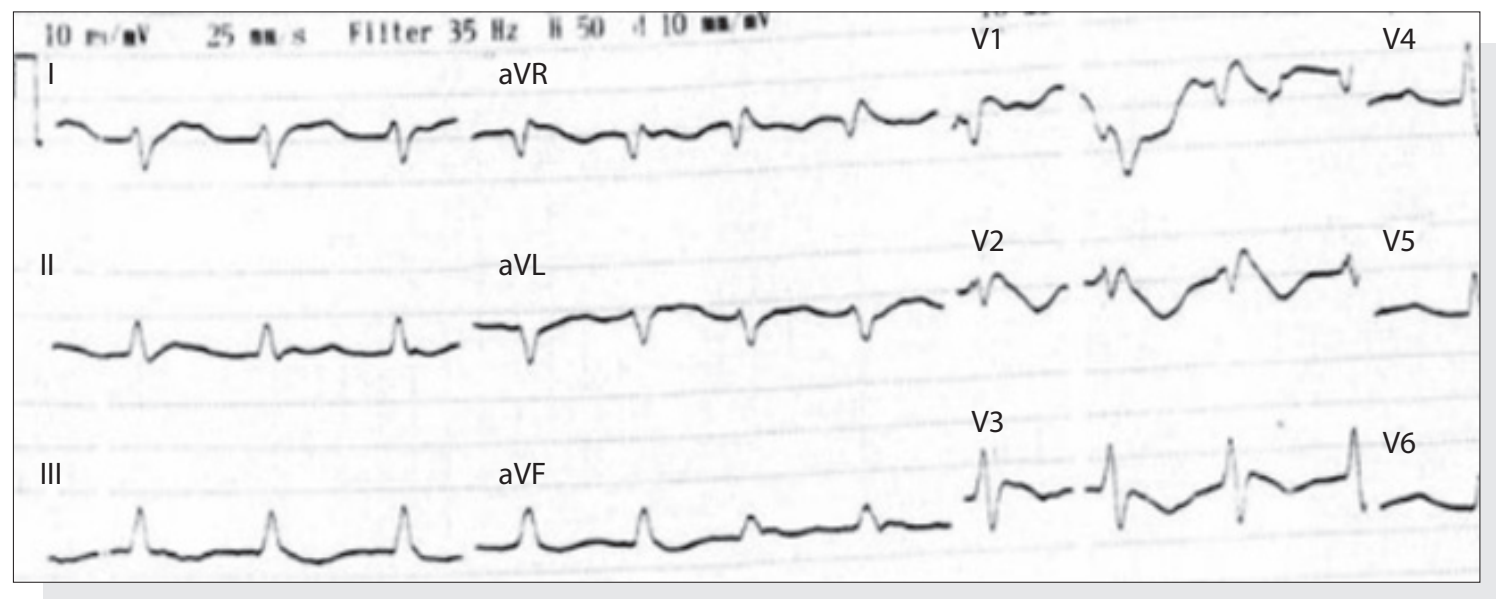

Figure 1. Accelerate idioventricular rhythm.

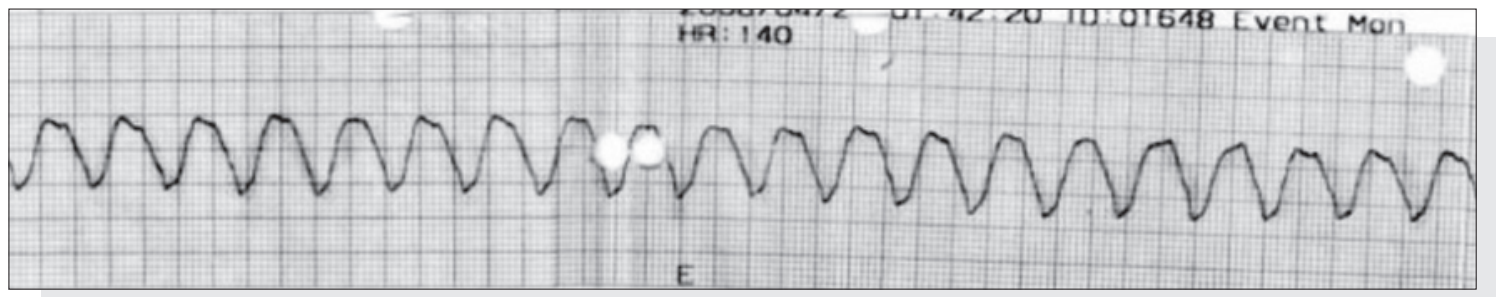

Figure 2. Ventricular tachycardia. 
was $110 / 60 \mathrm{mmHg}$. In ECG, a sinus rhytm with a rate of $90 /$ min was identified and the QRS duration was $134 \mathrm{~ms}$. Laboratory findings were otherwise normal. $\mathrm{NaHCO}_{3}$ administration of $1 \mathrm{mEq} / \mathrm{kg}$ every 4 hours was continued. After therapy, QRS duration shortened. The patient became conscious with spontaneous ventilation. She was then extubated and transferred to the coronoary intensive care unit. After a 3 day follow up in the coronary intensive care unit without additional problems, the patient was discharged with a total recovery.

\section{Discussion}

Propafenone may cause cardiac arrest through its proarrhytmic effects, either by causing new arrhytmias or worsening the present arrhytmia. These proarrhytmic effects may also be observed as bradicardias, conduction abnormalities (sinoatrial, atrioventricular or intraventricular blocks) or tachycardia (ventricular tachycardia). Rarely, ventricular flutter and/or fibrillation can be observed..$^{[5,6]}$ Thus, in this case malign arrhytmias were determined first as an accelerating idioventricular rhythm then as pulseless VT. It has been previously reported that intoxication with Group $1 \mathrm{C}$ antiarrhytmic agents has a higher mortality compared to many other types of intoxication. ${ }^{[7]}$ In a study of 120 patients, Köppel et al. ${ }^{[8]}$ reported that 34 of these patients were intoxicated with propafenone. Cardiac arrest developed in 29 of these patients and 27 of them did not respond to CPR. Stancak et al. ${ }^{[9]}$ reported a 28 year old male with $4500 \mathrm{mg}$ propafenone ingestion with suicidal intention. They reported that cardiopulmonary arrest developed in this case and no response to CPR was achieved. In a case reported by Üstündağ et al., ${ }^{[7]}$ a female patient with $7500 \mathrm{mg}$ propafenone ingestion was presented. In this case cardiopulmonary arrest developed in 2 hours after admission and the patient died after 45 minutes of resuscitation. Available data reveals that hemodynamically unstable patients who need resuscitation have higher mortality rates. Even in our case, cardiopulmonary arrest developed. The patient responded to our early, effective and long lasting CPR.

Seizures may be seen with propafenon overdose, especially in high dose ingestions. Rambourg-Schepens et al. ${ }^{[4]}$ reported a case with generalized seizure after 1 hour following propafenone intoxication. Our case presented with a depressed consciousness and developed an epileptic seizure.

Early monitoring, early diagnosis and early treatment was important to this patient's survival. Brubacher reported ${ }^{[10]}$ that $\mathrm{HCO}_{3}$ is considered by most toxicologists to be the treatment of choice for cardiac toxicity in the setting of sodium-channel blocker poisoning. It is reasonable to suspect that $\mathrm{HCO}_{3}$ would benefit patients with propafenone toxicity, but the literature in this setting is limited. Ovaska et al. ${ }^{[11]}$ reported a patient that was was managed with intravenous glucagon, sodium bicarbonate, hypertonic saline and this treatment was associated with a good outcome. Recently $D^{\prime}$ Orazio ${ }^{[12]}$ reported that sodium bicarbonate bolus and infusion shortened the QRS length to $90 \mathrm{~ms}$. To avoid persistent hypotension and ECG abnormalities, $1 \mathrm{mEq} / \mathrm{kg}$ sodium bicarbonate administration in every 4-6 hours is recommended. ${ }^{[13,14]}$ In another study, Yi et al reported that Insulin treatment improved survival and delayed the hemodynamic and electrocardiographic consequences of propafenone toxicity. They reported that insulin prevented the decline of mean arterial pressure and heart rate. Insulin also prevented the increase of PR interval and QRS duration. ${ }^{[15]}$ In our case, $\mathrm{NaHCO}_{3}$ in an appropriate dosage was initiated IV for hypotension and QRS widening. $\mathrm{NaHCO}_{3}$ therapy was maintained to retain ph of 7.50-7.55 until hypotension and QRS widening resolved.

When seizures occur, intervention with diazepam is recommended. In our case generalized tonic clonic type epileptic seizure was observed and treated with $5 \mathrm{mg}$ diazepam. Additional seizures were not observed.

Efficacy of external or internal pacemaker implementation in propafenone intoxication is controversial because it is known that electrical pacing threshold increases due to this drug. ${ }^{[16]}$ There are also reports that recommend hemodyalisis for treatment. ${ }^{[17]}$ Our case improved both electrocardiographically and clinically after resuscitation, so cardiac pacing and hemodyalisis were not considered and the patient was evaluated by clinical follow-up.

\section{Conclusion}

Sodium bicarbonate administration in the presence of hypotension and QRS widening are vital. $1 \mathrm{mEq} / \mathrm{kg}$ sodium bicarbonate administration every 4-6 hours is recommended until hypotension and QRS widening rsolve. Early diagnosis, aggressive treatment, meticulous monitoring and supportive care can be vital in propafenone intoxication.

\section{Conflict of Interest}

The authors declare that there is no potential conflicts of interest.

\section{References}

1. Clarot F, Goullé JP, Horst M, Vaz E, Lacroix C, Proust B. Fatal propafenone overdoses: case reports and a review of the literature. J Anal Toxicol 2003;27:595-9.

2. Vaughan Williams EM. Relevance of cellular to clinical electrophysiology in interpreting antiarrhythmic drug action. Am J Cardiol 1989;64:5J-9J.

3. Kerns W 2nd, English B, Ford M. Propafenone overdose. Ann 
Emerg Med 1994;24:98-103.

4. Rambourg-Schepens MO, Grossenbacher F, Buffet M, Lamiable D. Recurrent convulsions and cardiac conduction disturbances after propafenone overdose. Vet Hum Toxicol 1999;41:153-4.

5. Kolecki PF, Curry SC. Poisoning by sodium channel blocking agents. Crit Care Clin 1997;13:829-48.

6. Henry JA, Cassidy SL. Membrane stabilising activity: a major cause of fatal poisoning. Lancet 1986;1:1414-7.

7. Üstündağ $M$, Orak M, Güloğlu C, Özhasenekler A, Durgun HM. Lethal toxicity of propafenone in a case of suicidal attempt. Turk J Emerg Med 2007;7:132-5.

8. Köppel C, Oberdisse U, Heinemeyer G. Clinical course and outcome in class IC antiarrhythmic overdose. J Toxicol Clin Toxicol 1990;28:433-44.

9. Stancak B, Markovic P, Rajnic A, Petrikova V. Acute toxicity of propafenone in a case of suicidal attempt. Bratisl Lek Listy 2004; 105:14-7.

10. Brubacher J. Bicarbonate therapy for unstable propafenone- induced wide complex tachycardia. CJEM 2004;6:349-56.

11. Ovaska H, Ludman A, Spencer EP, Wood DM, Jones AL, Dargan PI. Propafenone poisoning-a case report with plasma propafenone concentrations. J Med Toxicol 2010;6:37-40.

12. D'Orazio JL, Curtis JA. Overdose of propafenone surreptitiously sold as "Percocet". J Emerg Med 2011;41:172-5.

13. Brazil E, Bodiwala GG, Bouch DC. Fatal flecainide intoxication. J Accid Emerg Med 1998;15:423-5.

14. Lovecchio F, Berlin R, Brubacher JR, Sholar JB. Hypertonic sodium bicarbonate in an acute flecainide overdose. Am J Emerg Med 1998;16:534-7.

15. Yi HY, Lee JY, Lee SY, Hong SY, Yang YM, Park GN. Cardioprotective effect of glucose-insulin on acute propafenone toxicity in rat. Am J Emerg Med 2012;30:680-9.

16. Eray O, Fowler J. Severe propafenone poisoning responded to temporary internal pacemaker. Vet Hum Toxicol 2000;42:289.

17. Burgess ED, Duff HJ. Hemodialysis removal of propafenone. Pharmacotherapy 1989;9:331-3. 